\title{
Effect of $\beta$-mercaptoetanol and cysteine on post-thawing quality and oxidative activity of ram sperm and on the viability of vitrified sheep embryos
}

\author{
[Efeito do $\beta$-mercaptoetanol e da cisteína sobre a qualidade e a atividade oxidativa do sêmen ovino após o \\ descongelamento e sobre a viabilidade de embriões ovinos vitrificados] \\ J. Pradieé $e^{1,2}$, T.F. Cardoso ${ }^{1,3}$, E.F. Silva ${ }^{1,3}$, A.O. Gonçalves ${ }^{1,2}$, G.D.A. Gastal ${ }^{1,2}$, C.E. Rosa ${ }^{6}$, \\ R.G. Mondadori ${ }^{1,4}$, L.M.C. Pegoraro ${ }^{5}$, A.D. Vieira ${ }^{1,2}$, T. Lucia Jr. ${ }^{1,2} *$ \\ ${ }^{1}$ ReproPel - Capão do Leão, RS \\ ${ }^{2}$ Faculdade de Veterinária - Pelotas, RS \\ ${ }^{3}$ Centro de Desenvolvimento Tecnológico - Pelotas, RS \\ ${ }^{4}$ Instituto de Biologia - Universidade Federal de Pelotas - Pelotas, RS \\ ${ }^{5}$ Embrapa Clima Temperado - Pelotas, RS \\ ${ }^{6}$ Instituto de Ciências Biológicas - Universidade Federal do Rio Grande - \\ Rio Grande, RS
}

\begin{abstract}
The effects of $\beta$-mercaptoethanol (BME) and cysteine on the viability and oxidative activity of ram sperm after thawing and on development in vitro and viability of vitrified sheep embryos were evaluated. Ejaculates from four rams were pooled and extended, composing six treatments: no antioxidants; $2 \mathrm{mM}$ BME; $5 \mathrm{mM}$ BME; $2 \mathrm{mM}$ BME and $5 \mathrm{mM}$ cysteine; $5 \mathrm{mM}$ BME and $5 \mathrm{mM}$ cysteine; and $5 \mathrm{mM}$ cysteine. Sperm motility, membrane and acrosome integrity, mitochondrial functionality, production of reactive oxygen species and total antioxidant capacity were similar across treatments $(\mathrm{P}>0.05)$. A medium with no antioxidant presented cleavage and blastocyst development rates $(60.3 \%$ and $33.6 \%$, respectively) similar $(\mathrm{P}>0.05)$ to those of a medium with $50 \mu \mathrm{M} \mathrm{BME}$ and $600 \mu \mathrm{M}$ cysteine $(64.3 \%$ and $36.6 \%$, respectively). Post-thawing viability of vitrified embryos was similar between media $(\mathrm{P}>0.05)$. Cysteine and BME had no influence on the post-thawing viability and oxidative activity of ram sperm and on the viability of vitrified sheep embryos.
\end{abstract}

Keywords: sheep embryos, antioxidant, reactive oxygen species, frozen ram sperm, vitrification

\section{RESUMO}

Foram avaliados os efeitos do $\beta$-mercaptoetanol (BME) e da cisteina sobre a viabilidade e a atividade oxidativa após o descongelamento do sêmen ovino e sobre o desenvolvimento in vitro e a viabilidade de embriões ovinos vitrificados. Ejaculados de quatro carneiros foram agrupados e diluidos, compondo seis tratamentos: sem antioxidantes; com BME 2mM; com BME 5mM; com BME 2mM e cisteina 5mM; com BME $5 \mathrm{mM}$ e cisteína $5 \mathrm{mM}$; e com cisteína $5 \mathrm{mM}$. Motilidade, integridade da membrana e do acrossoma, função mitocondrial, produção de espécies reativas de oxigênio e capacidade antioxidante total foram semelhantes entre os tratamentos $(P>0,05)$. Em um meio sem antioxidantes, as taxas de clivagem e de desenvolvimento embrionário até blastocisto $(60,3 \%$, e 33,6\%, respectivamente) foram semelhantes $(P>0,05)$ às obtidas em um meio comBME 50 $\mu$ M e cisteina $600 \mu M(64,3 \%$ e $36,6 \%$, respectivamente). A viabilidade pós-descongelamento dos embriões vitrificados não diferiu entre os meios $(P>0,05)$. O BME $e$ a cisteína não influenciaram a viabilidade $e$ a atividade oxidativa do sêmen ovino após o descongelamento e a viabilidade de embriões ovinos vitrificados.

Palavras-chave: embriões ovinos, antioxidantes, espécies reativas de oxigênio, sêmen ovino congelado, vitrificação

Recebido em 30 de maio de 2015

Aceito em 4 de março de 2016

*Autor para correspondência (corresponding author)

E-mail: thomaz@pq.cnpq.br 


\section{INTRODUCTION}

Ram spermatozoa are highly sensitive to structural and functional damages during freezing and thawing due to the high content of long-chain polyunsaturated fatty acids in their membrane and to the lack of antioxidants in their cytoplasm. Such injuries may result from oxidative stress and lipid peroxidation, due to the spermatozoa's exposure to reactive oxygen species (ROS) derived from their own metabolism (Sinha et al., 1996; Peris et al., 2007), which leads to premature capacitation (Bailey et al., 2000; Aisen et al., 2005). Therefore, the inclusion of substances with antioxidant properties in freezing extenders may prevent cryoinjuries in spermatozoa's membranes and organelles that may impair their post-thawing viability (Chatterjee and Gagnon, 2001). Many antioxidant additives have been tested in protocols for freezing ram sperm (Bucak et al., 2008; Maia et al., 2010), but due to their inconsistent results, further research in this field is justified.

Thiol antioxidant composts of low molecular weight, such as $\beta$-mercaptoetanol (BME), neutralize ROS production by inducing intracellular synthesis of glutathione (GSH) (Luberda, 2005; Hosseini et al., 2011). As GSH has no direct antioxidant effect, an increase in its concentration is stimulated through other pathways (Câmara et al., 2011). That occurs because BME promotes oxidation of cysteine, an aminoacid involved in GSH intracellular synthesis, into cystine. Even though cystine cannot be metabolized by the cell, BME reacts with cystine producing a disulfide mixture that allows cysteine to become available (Ishii et al., 1981; Takahashi et al., 2002), releasing BME to react with other cystine molecules. Although BME stimulates synthesis of mRNA and of essential mitochondrial proteins required to produce energy for sperm motility (Salem et al., 1988), antioxidant effects of BME and cysteine on post-thawing ram sperm viability were not yet reported.

In oocytes, cysteine's oxidation is mediated by cells of the cumulus oophurus-oocyte complex (COC) (Matos et al., 1997). In media for in vitro maturation (IVM) of oocytes, cysteine's availability appears to be limiting for GSH synthesis, especially because its concentration is commonly lower than that of cystine, due to selfoxidation (Matos et al., 2002). However, the low cysteine's available concentration during the first hours of IVM appears enough to guarantee GSH synthesis. Thus, the cystine generated by cysteine's oxidation may be reconverted in cysteine by the COC cells and incorporated by the embryo, generating GSH (Matos et al., 1997). Nevertheless, the effects of the inclusion of BME and cysteine in IVM media on sheep embryo development are still unknown.

This study included two experiments. Experiment 1 evaluated the effect of adding BME and cysteine to the freezing extender on the post-thawing viability and oxidative activity of ram sperm. Experiment 2 evaluated the effects of adding both BME and cysteine to the IVM medium on the development and viability of vitrified sheep embryos.

\section{MATERIAL AND METHODS}

In both experiments, all analyses were conducted by the same trained technician and all chemicals were obtained from Sigma-Aldrich Chemical Company (Saint Louis, MO, USA), unless stated differently. All experimental procedures were approved by UFPel's Ethics for Animal Experimentation Committee (protocol number $5541)$.

In Experiment 1, ejaculates were collected twice weekly using an artificial vagina from four rams of the Crioula Lanada breed (23 ejaculates per ram). The rams were 4-5 years old and kept under semi-extensive conditions at the Universidade Federal de Pelotas ( $31^{\circ} 46^{\prime} 3^{\prime \prime}$ South, 52 $26^{\prime} 55^{\prime \prime}$ West). Only ejaculates presenting sperm motility of $70 \%$ or greater and a score of sperm vigor equal or greater than three (in a scale from 1-5) were further processed. After determining spermatozoa concentration in a Neubauer chamber, ejaculates were pooled into a single sample containing $1 \times 10^{9}$ spermatozoa, with equal number of viable spermatozoa $(2.5 \mathrm{x}$ $10^{8}$ ) for each ram. The pooled sample was diluted in Tris-egg yolk-glycerol (Evans and Maxwell, 1987) and split in six treatments including: no antioxidants (control); $2 \mathrm{mM} \mathrm{BME;}$ $5 \mathrm{mM}$ BME; $2 \mathrm{mM}$ BME and $5 \mathrm{mM}$ cysteine; $5 \mathrm{mM}$ BME and $5 \mathrm{mM}$ cysteine; and $5 \mathrm{mM}$ cysteine. 
Sperm samples were stored in $0.25 \mathrm{~mL}$ straws containing $100 \times 10^{6}$ spermatozoa and frozen using a programmable freezer $\left(\right.$ TK $3000^{\circledR}$, Tetakon, Nutricell, Campinas-SP, Brazil), following a curve of $0.25^{\circ} \mathrm{C}$ per min, until reaching $5^{\circ} \mathrm{C}$. After stabilization for $2 \mathrm{~h}$, samples were cooled at $0.5^{\circ} \mathrm{C}$ per min until $-120^{\circ} \mathrm{C}$ and then immersed in liquid nitrogen. Subsequently, samples were thawed in a water bath at $37^{\circ} \mathrm{C}$ during 20 s.

All parameters of sperm quality were evaluated before freezing and after thawing. Sperm motility was also evaluated after one and two $h$ post-thawing, by optical microscopy at $200 \mathrm{X}$. The integrity of the sperm membrane and the acrosome and the mitochondrial functionality were evaluated using an epifluorescent microscope (Eclipse 80i, Nikon ${ }^{\circledR}$, Melville, NY, USA) at $400 \mathrm{X}$, with $450-520 \mathrm{~nm}$ filter wave length. In all analyses, 200 spermatozoa were counted per slide. After exposure to carboxyfluorescein diacetate and propidium iodide, spermatozoa with intact membrane presented green fluorescence, but fluorescence for those with damaged membrane was either red or simultaneously red and green (Harrison and Vickers, 1990). Acrosome integrity was evaluated using Arachis hypogaea FITC-PNA conjugate, considering that spermatozoa with intact acrosomes presented red fluorescence, normal conformation and acrosome with green fluorescence, whereas those without integer acrosome also presented red fluorescence, but their conformation was abnormal and their acrosome was not evident (Jiménez et al., 2003). Mitochondrial functionality was evaluated using rhodamine 123 solution: green fluorescence indicated functional mitochondria; no fluorescence indicated nonfunctional mitochondria (Evenson et al., 1982).

The ROS were evaluated through the cinetic test (Myhre and Fonnum, 2001). After thawing, sperm samples were placed in $1.5 \mathrm{~mL}$ tubes and centrifuged twice at $800 \mathrm{G}$ for $10 \mathrm{~min}$. After discharge of the supernatant, the resulting pellet was resuspended in $1 \mathrm{~mL}$ PBS without $\mathrm{Ca}$ and $\mathrm{Mg}$ and a $400 \mu \mathrm{l}$ aliquot was frozen for further evaluation of the total antioxidant capacity (TAC) against peroxide radicals. Thereafter, $600 \mu \mathrm{L}$ of 2',7'-dichlorodihydrofluorescein diacetate $\left(\mathrm{H}_{2} \mathrm{DCF}-\mathrm{DA}\right)$, a general oxidative stress fluorescent marker for ROS, were added to the solution $(40 \mu \mathrm{M}$ in PBS). After a second centrifugation, the pellet was resuspended and homogenized for $5 \mathrm{~s}$ in vortex, remaining incubated with the marker for $30 \mathrm{~min}$ at $36^{\circ} \mathrm{C}$. The sample was centrifuged again and washed with $600 \mu \mathrm{l}$ PBS to remove the excess of $\mathrm{H}_{2} \mathrm{DCF}$ DA. Then, $160 \mu \mathrm{L}$ of the sample were placed in 96-well plates (Corning $® 3912$ ) in triplicate, for evaluation of ROS, using a fluoremeter (Victor 2D, Perkin Elmer ${ }^{\circledR}$, Santa Clara, CA, USA), in 12 cycles with 4-min intervals, with agitation for $2 \mathrm{~s}$ before and after each cycle, at $36^{\circ} \mathrm{C}$. The ROS production was determined by the integration of the area of the fluorescence time curve, expressed per fluorescence unit $\times 10^{7}$.

The TAC was generated by the thermal decomposition at $36^{\circ} \mathrm{C}$ of the $2,2^{\prime}$-azobis (2metilpropionamidine) dihydrochloride (ABAP) (Amado et al., 2009). A $400 \mu \mathrm{L}$ aliquot previously stored at $-18^{\circ} \mathrm{C}$, for at most $15 \mathrm{~d}$, was thawed at room temperature, sonicated for $5 \mathrm{~s}$ and centrifuged at $800 \mathrm{G}$ for $10 \mathrm{~min}$. After discharging the resulting pellet, $125 \mu \mathrm{L}$ PBS and $10 \mu \mathrm{L}$ of each sample were added to 4 wells in a 96-well plate $\left(\right.$ Corning $\left.^{\circledR} 3912\right)$. In that plate, $7.5 \mu \mathrm{L}$ of Milli-Q water were added to two wells and $7.5 \mu \mathrm{L}$ of the ABAP solution $(20 \mu \mathrm{M})$ were added to the other two, both in duplicate. Then, $10 \mu \mathrm{L}$ of the $\mathrm{H}_{2}$ DCF-DA marker $(16 \mu \mathrm{M})$ were added to all wells. The evaluation was conducted in fluoremeter Victor 2D, Perkin Elmer ${ }^{\circledR}$, Santa Clara, CA, USA), during 30min with $5 \mathrm{~min}$ intervals at $36^{\circ} \mathrm{C}$, with $488-529$ wave length. The TAC was obtained by dividing the ROS areas with and without ABAP by the ROS area without ABAP (1/relative area).

In Experiment 2, ovaries collected from pubertal sheep at a local slaughterhouse were transported to the laboratory in a saline/gentamicin solution $(40 \mathrm{mg} / \mathrm{ml})$ at $30^{\circ} \mathrm{C}$. The COC were aspirated from $3-6 \mathrm{~mm}$ follicles with an $18 \mathrm{G}$ needle attached to a $10 \mathrm{~mL}$ syringe. The COC selected for IVM presented homogenous cytoplasm and compact cumulus oophurus cells and were cultured for IVM in TCM 199 containing: 20\% inactivated serum of sheep in estrous; $100 \mathrm{UI} / \mathrm{mL}$ penicillin; $100 \mu \mathrm{g} / \mathrm{mL}$ streptomycin; $5 \mu \mathrm{g} / \mathrm{mL}$ FSH; $5 \mu \mathrm{g} / \mathrm{mL} \mathrm{LH} ; 5 \mu \mathrm{g} / \mathrm{mL} \mathrm{FSH}$; and $1 \mu \mathrm{g} / \mathrm{mL}$ estradiol. Two media were tested, including: $50 \mu \mathrm{M}$ BME and $600 \mu \mathrm{M}$ cysteine $(\mathrm{n}=729)$; or no antioxidants $(\mathrm{n}=676)$. 
The IVM was conducted in four-well plates containing $400 \mu \mathrm{l}$ drops covered with mineral oil, during $24 \mathrm{~h}$, in an incubator at $39^{\circ} \mathrm{C}$, with $5 \%$ $\mathrm{CO}_{2}$ and saturated humidity. The $\mathrm{COC}$ were inseminated with fresh sperm collected from the same rams as described in Experiment 1, including $1 \times 10^{9}$ spermatozoa/mL extended $(\mathrm{v} / \mathrm{v})$ in Tris-egg yolk (Evans and Maxwell, 1987). Spermatozoa were selected through swim up, after incubating a $200 \mu \mathrm{L}$ sperm aliquot for $2 \mathrm{~min}$ in a conic tube containing $2 \mathrm{~mL}$ of Tris-egg yolk supplemented with $0.06 \mathrm{~g} / \mathrm{mL} \quad$ BSA and $0.022 \mathrm{~g} / \mathrm{mL}$ pyruvate. Then, $500 \mu \mathrm{L}$ of the supernatant was diluted in $500 \mu \mathrm{L}$ of SOF (Holm et al., 1991) with no amino acids and supplemented with $2 \%$ of inactivated serum of sheep in estrous, $50 \mu \mathrm{g} / \mathrm{mL}$ streptomycin and $50 \mathrm{UI} / \mathrm{mL}$ penicillin. That content was centrifuged at $200 \mathrm{G}$ for $5 \mathrm{~min}$. The potential zygotes were denuded and cultured for $8 \mathrm{~d}$ in SOF (Holm et al., 1991) supplemented with $0.4 \% \mathrm{BSA}$ at $39^{\circ} \mathrm{C}$, in a bag system with atmosphere including $5 \% \mathrm{CO}_{2}, 90 \% \mathrm{~N}_{2}$ and $5 \%$ $\mathrm{O}_{2}$ (Vajta et al., 1997).

Parthenogenetic activation was done by placing, on average, 15 oocytes in wells containing the IVM medium with no spermatozoa. Cleavage rates were determined on the second day after insemination (D2) and blastocyst development rates were determined on D7. The embryos were vitrified in open pulled straws (Vajta et al., 1998). Post-thawing embryo viability was evaluated by re-expansion and hatching rates.

In Experiment 1, the integrity of the sperm membrane and acrosome after thawing were compared across treatments by analyses of variance, with comparisons of means by the Tukey test. The other responses were compared by Kruskal-Wallis analysis of variance for nonparametric data, due to lack of normality. Sperm motility was also compared between two postthawing periods ( 1 and $2 \mathrm{~h}$ ). In Experiment 2, rates of cleavage, development to blastocyst, reexpansion and hatching were compared across treatments by qui-square tests. All statistical analyses were conducted with Statistix ${ }^{\circledR}$ (2008).

\section{RESULTS}

In Experiment 1, before freezing, sperm motility was $80.2 \pm 9.0 \%$, membrane integrity was $74.0 \pm$ $18.3 \%$, acrosome integrity was $51.6 \pm 17.5 \%$ and mitochondrial functionality was $77.9 \pm 15.4 \%$. No differences were observed among treatments $(\mathrm{P}>0.05)$ for any of the evaluated parameters of post-thawing sperm quality (Tab. 1). Sperm motility after thawing was similar in the two evaluated periods $(\mathrm{P}>0.05): 28.2 \pm 0.6 \%$ after $1 \mathrm{~h}$; and $19.6 \pm 0.7 \%$ after $2 \mathrm{~h}$. The production of ROS and the TAC against peroxide radicals after thawing did not differ $(\mathrm{P}>0.05)$ among treatments (Tab. 2).

In Experiment 2 (Tab. 3), similar cleavage rates $(\mathrm{P}>0.05)$ were observed for the control and for the medium including BME and cysteine $(60.3 \%$ and $64.3 \%$, respectively).

Blastocyst development rates did not differ $(\mathrm{P}>0.05)$ between treatments. After both 24 and $48 \mathrm{~h}$, post-thawing embryo viability was similar between treatments $(\mathrm{P}>0.05)$.

Table 1. Post-thawing motility, membrane integrity, acrosome integrity and mitochondrial activity for ram sperm frozen in extenders including $\beta$-mercaptoethanol (BME) and cysteine (Experiment 1)

\begin{tabular}{lcccc}
\hline Extenders & Motility (\%) & $\begin{array}{c}\text { Membrane } \\
\text { integrity (\%) }\end{array}$ & $\begin{array}{c}\text { Acrosome } \\
\text { integrity (\%) }\end{array}$ & $\begin{array}{c}\text { Mitochondria } \\
\text { 1 activity (\%) }\end{array}$ \\
\hline Control & $31.3 \pm 1.6$ & $42.3 \pm 3.7$ & $40.9 \pm 1.9$ & $64.5 \pm 3.0$ \\
$2 \mathrm{mM} \mathrm{BME}$ & $25.6 \pm 1.4$ & $40.4 \pm 3.8$ & $35.9 \pm 2.8$ & $58.0 \pm 2.9$ \\
$5 \mathrm{mM} \mathrm{BME}$ & $25.9 \pm 1.4$ & $42.1 \pm 4.8$ & $38.8 \pm 2.2$ & $61.9 \pm 2.8$ \\
$5 \mathrm{mM}$ cysteine & $23.9 \pm 1.6$ & $38.9 \pm 4.0$ & $44.1 \pm 1.7$ & $62.0 \pm 3.4$ \\
$2 \mathrm{mM}$ BME + 5 mM cysteine & $24.5 \pm 1.6$ & $45.1 \pm 3.5$ & $40.8 \pm 3.3$ & $55.3 \pm 3.6$ \\
$5 \mathrm{mM} \mathrm{BME}+5 \mathrm{mM}$ cysteine & $26.0 \pm 1.6$ & $42.7 \pm 2.9$ & $45.6 \pm 2.0$ & $56.6 \pm 3.8$ \\
\hline
\end{tabular}


Table 2. Reactive oxygen species (ROS) and total antioxidant capacity against peroxide radicals (TAC) after thawing for ram sperm frozen in extenders including $\beta$-mercaptoethanol (BME) and cysteine (Experiment 1)

\begin{tabular}{lcr}
\hline Extenders & ROS (Field fluorescence*10 ${ }^{7}$ ) & TAC (1/relative area) \\
\hline Control & $1.3 \pm 0.1(1.1)$ & $82.2 \pm 7.7(71.7)$ \\
$2 \mathrm{mM} \mathrm{BME}$ & $1.1 \pm 0.1(1.1)$ & $96.2 \pm 10.5(88.4)$ \\
$5 \mathrm{mM} \mathrm{BME}$ & $1.1 \pm 0.1(0.9)$ & $113.9 \pm 35.5(71.2)$ \\
$5 \mathrm{mM}$ cysteine & $1.2 \pm 0.1(1.1)$ & $82.2 \pm 5.7(75.0)$ \\
$2 \mathrm{mM} \mathrm{BME}+5 \mathrm{mM}$ cysteine & $1.1 \pm 0.5(1.0)$ & $75.3 \pm 7.6(71.7)$ \\
$5 \mathrm{mM} \mathrm{BME}+5 \mathrm{mM}$ cysteine & $1.0 \pm 0.1(0.9)$ & $108.6 \pm 14.3(96.1)$ \\
\hline
\end{tabular}

Means \pm SEM did not differ $(\mathrm{P}>0.05)$; value in parentheses is the median.

Table 3. Cleavage, development to the blastocyst stage (D7) and post-thawing viability of vitrified sheep embryos in a medium including $50 \mu \mathrm{M} \beta$-mercaptoethanol (BME) and $600 \mu \mathrm{M}$ cysteine (Experiment 2)

\begin{tabular}{lcccc}
\hline Media & $\begin{array}{c}\text { Cleavage } \\
(\%)\end{array}$ & $\begin{array}{c}\text { Blastocyst } \\
\text { development }(\%)\end{array}$ & \multicolumn{2}{c}{$\begin{array}{c}\text { Post-thawing viability (\%) } \\
\end{array}$} \\
& & & $\begin{array}{c}\text { Re-expansion } \\
(24 \mathrm{~h})\end{array}$ & $\begin{array}{c}\text { Hatching }(48 \\
\mathrm{h})\end{array}$ \\
\cline { 3 - 5 } Control & $434 / 720(60.3)$ & $146 / 434(33.6)$ & $10 / 13(76.9)$ & $4 / 13(30.8)$ \\
BME and cysteine & $435 / 676(64.3)$ & $161 / 435(36.6)$ & $13 / 24(54.2)$ & $7 / 24(29.2)$ \\
\hline
\end{tabular}

Rates did not differ across treatments $(\mathrm{P}<0.05)$.

\section{DISCUSSION}

This was the first study to evaluate potential post-thawing antioxidant effects of BME and cysteine considering ram sperm quality and viability of vitrified sheep embryos produced in vitro as responses altogether. Acceptable rates of embryo development, re-expansion and hatching were obtained in Experiment 2, with $50 \mu \mathrm{M}$ BME associated to $600 \mu \mathrm{M}$ cysteine. Thus, the tested combination of antioxidants did not impair the development of sheep embryos, contradicting previous reports for cattle embryos (Matos et al., 2002). However, even though BME facilitates cysteine's absorption through the transport of cystine, improving the synthesis of GSH (Ishii et al., 1981), the tested antioxidants did not benefit sheep embryo development. Supplementing IVM medium with increased BME concentrations to improve embryo development may be questionable, since BME may lead to toxicity at concentrations greater than $50 \mu \mathrm{M}$, as observed for bovine embryos (Mori et al., 2006). Our results suggest that supplementation of IVM medium with BME may be feasible when associated with cysteine, since no apparent toxicity was observed at the tested concentrations, but further research is still necessary to investigate concentrations distinct from those tested in the present study and the role of such association of antioxidants during in vitro embryo maturation and culture, separately.

In Experiment 1, BME and cysteine were added to the extender before freezing, in opposition to studies with frozen sperm of bulls (Bilodeau et al., 2001), boars (Yamaguchi and Funahashi, 2012) and rams (Salem et al., 1988; Bucak et al., 2008), in which antioxidants were added to extenders after thawing. The inclusion of antioxidants prior to freezing was aimed to minimize the production of superoxide radicals that commonly occur during all steps of sperm cryopreservation (Chatterjee and Gagnon, 2001). However, the antioxidants may have been consumed before thawing, due to their prolonged contact with spermatozoa during cooling, freezing and thawing, which may explain their lack of effect on ROS production and on TAC. On the other hand, the prolonged exposure to antioxidants did not harm post-thawing sperm viability, indicating that BME and cysteine 
apparently were not cytotoxic at the tested concentrations. It is possible that spermatozoa are incapable of metabolizing those antioxidants as other cells do, in which case BME and cystein might react forming a mixed disulfide cysteine that shuts the cysteine molecule down inside the spermatozoa, returning it to its reduced form (Ishii et al., 1981). In such form, cysteine would serve as a substrate for GSH synthesis (Matos et al., 1997; Bai et al., 2008). Although supplementation of extenders with GSH itself and other antioxidants can protect spermatozoa against lipid peroxidation, their benefits for postthawing viability are controversial not only for ram sperm (Bucak et al., 2008; Câmara et al., 2011), but also for the sperm of bulls (Bilodeau et al., 2001) and bucks (Sinha et al., 1996). Cryotolerance of boar sperm can be improved with supplementation of freezing extenders with GSH, although such effect may be influenced by the individual freezing ability of specific ejaculates (Yeste et al., 2014). Trials previously conducted at our laboratory indicated that BME was detrimental for post-thawing sperm quality at concentrations greater than $5 \mathrm{mM}$, likely due to toxicity (unpublished data). Also, BME did not benefit ram sperm motility $2 \mathrm{~h}$ after thawing, contradicting findings reported for bull sperm (Bilodeau et al., 2001). A potential cryoprotectant effect of cysteine at the same tested concentration, as reported elsewhere (Bucak et al., 2008), was not confirmed by our results. Future studies may test distinct periods for inclusion of antioxidants in freezing extenders.

\section{CONCLUSIONS}

Addition of $\beta$-mercaptoethanol (BME) and cysteine to the freezing extender, alone or associated, did not influence the post-thawing quality and oxidative activity of ram sperm. Embryo development was unaffected by inclusion of $50 \mu \mathrm{M}$ BME and $600 \mu \mathrm{M}$ cysteine in the in vitro maturation medium. The tested antioxidants neither impaired nor improved the viability of vitrified sheep embryos produced in vitro.

\section{ACKNOWLEDGEMENTS}

This research was funded with a scholarship given to the first author by CAPES.

\section{REFERENCES}

AISEN, E.G.; QUINTANA, M.; MEDINA, V. et al. Ultramicroscopic and biochemical changes in ram spermatozoa cryopreserved with trehalose-based hypertonic extenders. Cryobiology, v.50, p.239-249, 2005.

AMADO, L.L.; GARCIA, M.L.; RAMOS, P.B. et al. A method to measure total antioxidant capacity against peroxyl radicals in aquatic organisms: application to evaluate microcystins toxicity. Sci. Total Environ., v.407, p.2115-2123, 2009.

BAI, J.; HOU, J.; GUAN, F. et al. Effect of $\beta$ mercapoethanol and cysteine supplementation during in vitro maturation on the developmental competence of oocytes from hormone-stimulated lambs. Theriogenology, v.70, p.758-764, 2008.

BAILEY, J.L.; BILODEAU, J.F.; CORMIER, N. Semen cryopreservation in domestic animals: a damaging and capacitating phenomenon. J. Androl., v.21, p.1-7, 2000 .

BILODEAU, J.F.; BLANCHETTE, S.; GAGNON, C.; SIRARD, M.A. Thiols prevent $\mathrm{H}_{2} \mathrm{O}_{2}$-mediated loss of sperm motility in cryopreserved bull semen. Theriogenology, v.56, p.275-286, 2001.

BUCAK, M.N.; ATESSAHIN, A.; YÜCE, A. Effect of anti-oxidants and oxidative stress parameters on ram semen after the freeze-thawing process. Small Ruminant Res., v.75, p.128-134, 2008.

CÂMARA, D.R.; MELLO-PINTO, M.M.C.; PINTO, L.C. et al. Effects of reduced glutathione and catalase on the kinematics and membrane functionality of sperm during liquid storage of ram semen. Small Ruminant Res., v.100, p.44-49, 2011.

CHATTERJEE, S.; GAGNON, C. Production of reactive oxygen species by spermatozoa undergoing cooling, freezing and thawing. Mol. Reprod. Dev., v.59, p.451-458, 2001.

EVANS, G.; MAXWELL, W.M.C. Frozen storage of semen. In: EVANS, G. (Ed.). Salamon's artificial insemination of sheep and goats. Sydney: Butterworths Pty, 1987. p.122-139.

EVENSON, D.P.; DARZYNKIEWICZ， Z.; MELAMED, M.R. Simultaneous measurement by flow cytometry of sperm cell viability and mitochondrial membrane potential related to cell motility. J. Histochem. Cytochem., v.30, p.279-280, 1982.

HARRISON, R.A.P.; VICKERS, S.E. Use of fluorescent probes to assess membrane integrity in mammalian spermatozoa. J. Reprod. Fert., v.88, p.343-352, 1990. 
HOLM, P.; IRVINE, B.; ARMSTRONG, D.T.; SEAMARK, R.F. In vitro production of sheep blastocysts from IVM-oocytes using frozen semen and oviduct epithelial cell co-culture for IVF. Theriogenology, v.35, p.214, 1991.

HOSSEINI, S.O.; AGHAEE, F.; HOSSEINI, S.M. et al. Effect of culture condition and cell-permeable superoxide dismutase on levels of reactive oxygen species (ROS) production in "in vitro" produced sheep embryos. Small Ruminant Res., v.97, p.88-93, 2011.

ISHII, T.; BANNAI, S.; SUGITA, Y. Mechanism of growth stimulation of $\mathrm{L} 1210$ cells by $\beta$ mercaptoethanol in vitro: role of the mixed disulfide of $\beta$-mercaptoethanol and cysteine. J. Biol. Chem., v.256, p.12387-12392, 1981.

JIMÉNEZ, I.; GONZÁLEZ-MÁRQUEZ, H.; ORTIZ, R. et al. Changes in the distribution of lectin receptors during capacitation and acrosome reaction in boar spermatozoa. Theriogenology, v.59, p.1171-1180, 2003.

LUBERDA, Z. The role of glutathione in mammalian gametes. Reprod. Biol., v.5, p.5-17, 2005.

MAIA, M.S.; BICUDO, S.D.; SICHERLE, C.C. et al. Lipid peroxidation and generation of hydrogen peroxide in frozen-thawed ram semen cryopreserved in extenders with antioxidants. Anim. Reprod. Sci., v.122, p.118-123, 2010.

MATOS, D.G.; FURNUS, C.C.; MOSES, D.F Glutathione synthesis during in vitro maturation of bovine oocytes: role of cumulus cells. Biol. Reprod., v.57, p.1420-1425, 1997.

MATOS, D.G.; HERRERA, C.; CORTVRINDT, R. et al. Cysteamine supplementation during in vitro maturation and embryo culture: a useful tool for increasing the efficiency of bovine in vitro embryo production. Mol. Reprod. Dev., v.62, p.203-209, 2002.

MORI, M.; OTOI, T.; WONGSRIKEAO, P. et al. Effects of $\beta$-mercaptoethanol and cycloheximide on survival and DNA damage of bovine embryos stored at $4^{\circ} \mathrm{C}$ for $72 \mathrm{~h}$. Theriogenology, v.65, p.1322-1332, 2006.

MYHRE, O.; FONNUM, F. The effect of aliphatic, naphthenic, and aromatic hydrocarbons on production of reactive oxygen species and reactive nitrogen species in rat brain synaptosome fraction: the involvement of calcium, nitric oxide synthase, mitochondria, and phospholipase A. Biochem. Pharmacol., v.62, p.119-128, 2001.
PERIS, S.I.; BILODEAU, J.F.; DUFOUR, M.; BAILEY, J.L. Impact of cryopreservation and reactive oxygen species on DNA integrity, lipid peroxidation, and functional parameters in ram sperm. Mol. Reprod. Dev., v.74, p.878-892, 2007.

SALEM, M.H.; ABDEL-KEREIM, M.A.; SELIM, A.R. et al. Effect of incubation conditions, inhibitors, B-mercaptoethanol and testosterone on RNA synthesis in ram spermatozoa. Theriogenology, v.30, p.339-347, 1988.

Statistix analytical software. Version 9. Tallahassee: SAS Institute, 2008.

SINHA, M.P.; SINHA, A.K.; SINGH, B.K.; PRASAD, R.L. The effect of glutathione on the motility, enzyme leakage and fertility of frozen goat semen. Anim. Reprod. Sci., v.41, p.237-243, 1996.

TAKAHASHI, M.; NAGAI, N.; OKAMURA, N.; TAKAHASHI, $H$. Promoting effect of bmercaptoethanol on in vitro development under oxidative stress and cystine uptake of bovine embryos. Biol. Reprod., v.6, p.562-567, 2002.

VAJTA, G.; HOLM, P.; GREVE, T.; CALLESEN, H. The submarine incubation system a new tool for in vitro embryo culture: a technique report. Theriogenology, v.48, p.1379-1395, 1997.

VAJTA, G.; HOLM, P.; KUWAYAMA, M. et al. Open pulled straws (OPS) vitrification: a new way to reduce cryoinjuries of bovine ova embryos. Mol. Reprod. Dev., v.51, p.53-58, 1998.

YAMAGUCHI, S.; FUNAHASHI, H. Effect of the addition of beta-mercaptoethanol to a thawing solution supplemented with caffeine on the function of frozenthawed boar sperm and on the fertility of sows after artificial insemination. Theriogenology, v.77, p.92632, 2012.

YESTE, M.; ESTRADA, E.; PINART, E. et al. The improving effect of reduced glutathione on boar sperm cryotolerance is related with the intrinsic ejaculate freezability. Cryobiology, v.68, p.251-261, 2014. 